\title{
Penilaian Kemampuan Kawasan Resapan Air (Studi Kasus Mata Air Umbulan)
}

\author{
Ali Masduqi ${ }^{1}$, Amien Widodo ${ }^{2}$, Mahendra A M..$^{3)}$, Tatas ${ }^{4)}$ \\ 1) Jurusan Teknik Lingkungan FTSP ITS, Surabaya \\ 2) Jurusan Teknik Geofisika FTSP ITS, Surabaya \\ 3,4) Jurusan Teknik Sipil FTSP ITS, Surabaya \\ Email: mahendrasipil@gmail.com
}

\begin{abstract}
Utilization of groundwater continues to increase, it may cause a negative impact on conditions of groundwater and its environment, like the reduced quantity and quality, sea water intrusion and land subsidence. Umbulan Spring in Pasuruan is one of the largest water source is in East Java. Potential is contained 5000 liters/sec. Land conditions into catchment Umbulan mostly forested with mountain topography. However, the recharge area began to change in landuse. This study is an early stage identification of infiltration capabilities on catchment area using the initial measurements using infiltration double rings. Research taken at three points, Village Tosari, Lumbang, and Winongan. Based on the results of research and testing in the area of infiltration in a row at $48 \mathrm{~mm} / \mathrm{hr}, 84 \mathrm{~mm} / \mathrm{hour}$, and $60 \mathrm{~mm} / \mathrm{hour}$.
\end{abstract}

Kata kunci: Umbulan, infiltration, double rings.

\section{Abstrak}

Pemanfaatan air tanah yang terus meningkat, dapat menimbulkan dampak negatif terhadap kondisi air tanah itu sendiri maupun lingkungan di sekitarnya, diantaranya berkurangnya kuantitas dan kualitas air tanah, penyusupan air laut dan amblesan tanah. Mata Air Umbulan di Kecamatan Winongan Kabupaten Pasuruan merupakan salah satu sumber air terbesar yang ada di Propinsi Jawa Timur. Potensi yang terkandung pada mata air tersebut adalah sebesar 5000 liter/detik. Kondisi lahan yang menjadi daerah tangkapan hujan Mata Air Umbulan sebagian besar berupa hutan dengan topografi pegunungan. Akan tetapi kondisi lingkungan yang menjadi penyokong utama terhadap kontribusi air ke Mata Air Umbulan mulai mengalami perubahan tata guna lahan. Penelitian ini merupakan tahap awal identifikasi kemampuan resapan daerah imbuhan air tanah dengan menggunakan metode melakukan pengukuran awal menggunakan alat ukur infiltrasi double rings. Penelitian diambil di tiga titik yaitu Desa Tosari, Lumbang, dan Winongan. Berdasarkan hasil penelitian dan pengujian di daerah tersebut laju infiltrasi berturut-turut sebesar 48 mm/jam, 84 mm/jam, dan 60 mm/jam.

Kata kunci: Umbulan, infiltrasi, double rings.

\section{Pendahuluan}

\subsection{Latar Belakang}

Air menopang kehidupan manusia, termasuk kehidupan dan kesinambungan rantai pangan mahluk hidup di bumi. Oleh karena itu Perserikatan Bangsa Bangsa (PBB) mendeklarasikan bahwa air merupakan hak azasi manusia; artinya, setiap manusia di muka bumi ini mempunyai hak dasar yang sama terhadap pemakaian air.

Mata Air Umbulan yang terletak di Kecamatan Winongan Kabupaten Pasuruan merupakan salah satu sumber air terbesar yang ada di Propinsi Jawa Timur. Potensi yang terkandung pada mata air tersebut adalah sebesar 5000 liter/detik. Kondisi lahan yang menjadi 
daerah tangkapan hujan Mata Air Umbulan sebagian besar berupa hutan dengan topografi pegunungan. Akan tetapi kondisi lingkungan yang menjadi penyokong utama terhadap kontribusi air ke Mata Air Umbulan mulai mengalami perubahan tata guna lahan. Pembalakan liar dan berubahnya lahan hijau menjadi areal industri dan pemukiman akan mengakibatkan perubahan daya resap lahan. Jika pada awalnya tutupan lahan berupa hutan, semak, dan kawasan hijau lainnya berubah menjadi lahan kedap air, maka jumlah air yang menyerap ke dalam tanah akan menjadi berkurang sehingga debit air yang keluar dari Mata Air Umbulan dimungkinkan akan berkurang.

\subsection{Perumusan dan Pembatasan Ma- salah}

Penelitian awal ini mengenai kawasan resapan air yang difokuskan pada peniliaian kemampuan infiltrasi daerah tangkapan hujan di Mata Air Umbulan. Adapun rumusan masalah pada penelitian ini adalah bagaimanakah kemampuan lahan di sekitar Mata Air Umbulan dalam meresapkan air hujan yang jatuh di atasnya?

\subsection{Tujuan}

Tujuan dari penelitian ini berkaitan dengan latar belakang masalah yang terdapat di lokasi penelitian, yaitu mengetahui kemampuan lahan di sekitar Mata Air Umbulan dalam meresapkan air hujan dengan melakukan pengambilan data langsung di lapangan.

\section{Metodologi}

\subsection{Klasifikasi Tanah}

Menurut kemampuan tanah untuk meluluskan air, tanah diklasifikasikan menjadi:

- Tanah pervious (lulus air)

Prosentase pori dalam tanah besar, sifat transmisi tanah baik, tahanan terhadap aliran vertikal kecil, kehilangan energi disebabkan oleh aliran horizontal. Tanah jenis ini didominasi oleh partikel berbutiran kasar. Adanya kandungan bahan organik membuat tanah menjadi gembur dan mudah meluluskan air. Pori-pori dalam tanah dapat terbentuk oleh akar tumbuhan atau binatang (misalnya cacing). Pori macam ini disebut 'biopores".

- Tanah semi pervious (semi lulus air)

Sifat transmisi relatif kurang baik. Aliran horizontal sampai dengan jarak tertentu dapat diabaikan. Tahanan terhadap aliran vertikal tak dapat diabaikan.

- Tanah Impervious (kedap air)

Sifat transmisi sangat buruk, tahan vertikal besar, dan aliran horizontal diabaikan. Dalam istilah pertanian, tanah dengan sifat-sifat ini disebut "tanah berat", karena pengolahannya tidak mudah. Pada musim kemarau tanah jenis ini kering dan retak-retak. Kehilangan air besar diawal musim hujan, namun setelah hujan berlangsung, sulit menyerap air lagi, karena pori-pori tanah yang kecil sudah dipenuhi oleh air (jenuh). Apabila terjadi genangan, maka genangan akan bertahan cukup lama apabila evaporasi berjalan lambat.

Dalam perhitungan hidrologi kondisi struktur tanah merupakan salah satu 
faktor yang diperhitungkan dalam koefisien pengaliran.

\subsection{Infiltrasi dan Perkolasi}

Laju maksimum air yang dapat berinfiltrasi ke dalam tanah kering berkurang, mulai dari harga tertinggi sampai harga terendah, dan selanjutnya mencapai konstan \pm 1 a' 3 jam dari saat awal. Harga yang mendekati harga konstan memberikan gambaran mengenai geometri pori dalam top soil yang bervariasi dengan tekstur tanah dan sangat dipengaruhi oleh struktur tanah.

Laju infiltrasi untuk beberapa jenis tanah dapat dilihat pada Tabel 1.

Tabel 1. Laju infiltrasi

\begin{tabular}{lll}
\hline Jenis tanah & $\begin{array}{l}\text { Total } \\
\text { infiltrasi } \\
\text { setelah } \\
\end{array}$ & $\begin{array}{l}\text { Laju infiltrasi } \\
\text { setelah } \\
3 \text { jam }(\mathrm{mm} / \mathrm{mam})\end{array}$ \\
\hline $\begin{array}{l}\text { Coarse textured } \\
\text { soil }\end{array}$ & $150-300$ & $15-20$ \\
\hline $\begin{array}{l}\text { Medium } \\
\text { textured soil }\end{array}$ & $30-100$ & $5-10$ \\
\hline $\begin{array}{l}\text { Fine textured } \\
\text { soil }\end{array}$ & $30-70$ & $1-5$ \\
\hline
\end{tabular}

Tanah retak lebih banyak menyerap air (100-200 mm), tetapi retakan dapat tertutup apabila terjadi runtuhan tanah. Pada laju infiltrasi akhir, kondisi sama dengan k pada keadaan jenuh.

Proses dimana air meresap masuk atau diserap tanah, yang besarnya daya serap ini berbeda dilihat dari kondisi tanahnya. Tiap permukaan tanah mempunyai kapasitas peresapan (kapasitas infiltrasi) yaitu kemampuan maksimal dari tanah untuk menyerap air hujan yang jatuh diatasnya $\left(\mathrm{f}_{\mathrm{p}}\right)$. Syarat dari proses infiltrasi dinyatakan sebagai berikut:
- Bila $\mathrm{I}<\mathrm{f}_{\mathrm{p}} \rightarrow$ seluruh hujan akan meresap ke dalam tanah $\left(\mathrm{f}_{0}=\mathrm{I}\right)$, tidak terjadi aliran permukaan.

- $\quad$ Bila $\mathrm{I}>\mathrm{f}_{\mathrm{p}} \rightarrow$ sebagian hujan akan meresap ke dalam tanah $\left(\mathrm{f}_{0}=\mathrm{f}_{\mathrm{p}}\right)$, terjadi aliran permukaan.

Faktor-faktor yang mempengaruhi terjadinya infiltrasi adalah sebagai berikut:

- ketinggian lapisan air di atas permukaan tanah

- macam tanah (tanah liat, tanah berpasir dan lain sebagainya)

- banyaknya moisture tanah yang sudah ada dalam lapisan tanah

- keadaan permukaan dan penutup tanah

- transmisibiliti massa tanah

Dalam suatu daerah aliran, besarnya kapasitas infiltrasi dapat berubah-ubah karena adanya perubahan musim. Selain diakibatkan perubahan musim, perubahan kapasitas infiltrasi juga erat kaitannya dengan perubahan tutupan lahan (tata guna lahan). Untuk mengetahui besarnya kapasitas infiltrasi suatu lahan dapat dilakukan pengukuran dengan menggunakan alat infiltrometer.

Infiltrometer digunakan untuk menetapkan infiltrasi kumulatif, laju infiltrasi, sorptivitas, dan kapasitas infiltrasi. Ada dua bentuk ring infiltrometer, yaitu single ring infiltrometer dan double atau concentric-ring infiltrometer. Single ring infiltrometer umumnya berukuran diameter $10-50 \mathrm{~cm}$ dan panjang atau tinggi $10-20 \mathrm{~cm}$. Ukuran double ring infiltrometer adalah ring pegukur/ring dalam umunya berdiameter $10-20 \mathrm{~cm}$, sedangkan ring bagian luar (ring penyangga/buffer ring) berdiameter 50 
$\mathrm{cm}$. Untuk tujuan tertentu sering digunakan ukuran ring yang lebih besar atau lebih kecil. Namun demikian, pengguaan ring yang terlalu kecil juga menyebabkan semakin tingginya tingkat kesalahan (error) pengukuran (Tricker, 1978).

Menurut Sosrodarsono dan Takeda (1993), penggunaan double ring infiltrometer (Gambar 1), lingkaran luar digunakan untuk mencegah peresapan keluar dari air dalam lingkaran tengah setelah meresap ke dalam tanah. Ditujukan untuk mengurangi pengaruh rembesan lateral. Oleh karena adanya rembesan lateral, sering menyebabkan hasil pengukuran dari alat ini menjadi tidak mudah untuk diekstrapolasikan ke dalam skala lapangan.

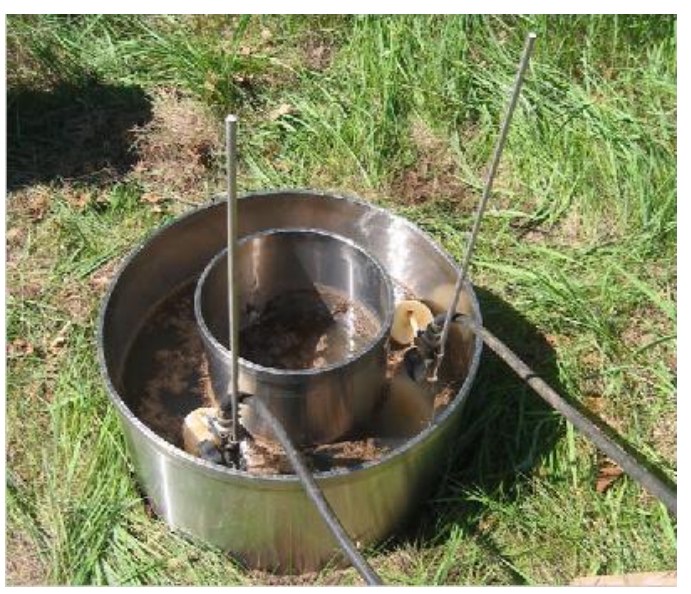

Gambar 1. Double Ring Infiltrometer

Menurut Sosrodarsono dan Takeda (1993) kedua jenis alat ukur infiltrasi ini mempunyai persoalan-persoalan yang sama yaitu:

a. Efek pukulan butir-butir hujan tidak diperhitungkan.

b. Efek tekanan udara dalam tanah tidak terjadi. c. Struktur tanah sekeliling dinding tepi alat itu telah terganggu pada waktu pemasukannya ke dalam tanah.

Menurut Dunne dan Leopold (1978) dalam Asdak (2010), dengan cara ini hasil laju infiltrasi yang diperoleh biasanya lebih besar daripada keadaan yang berlangsung di lapangan (infiltrasi dari curah hujan), yaitu 2-10 kali lebih besar.

Pengukuran kapasitas infiltrasi dilakukan dengan menggunakan single dan double ring infiltrometer. Dimana kedua alat tersebut terbuat dari baja untuk double ring infiltrometer diameter ring tengah $16,5 \mathrm{~cm}$ serta tinggi 25 $\mathrm{cm}$, dan ring luar berdiameter $27,5 \mathrm{~cm}$ dengan tinggi $15 \mathrm{~cm}$. Sedangkan untuk single ring infiltrometer merupakan ring yang hanya menggunakan ring tengah double ring infiltrometer. Cara penggunaanya sebagai berikut:

a. Double ring dimasukkan ke dalam tanah sampai sedalam separuh tinggi alat, dengan kedudukan diusahakan tegak lurus serta tanah dalam silinder dijaga jangan sampai rusak atau pecah.

b. Untuk menghindari kerusakan struktur tanah dalam silinder, maka sebelum dituangkan air terlebih dahulu permukaan tanah ditutup plastik, baru kemudian dituangkan diatas plastik tersebut.

c. Sebelum penuangan air pada silinder tengah, maka silinder luar sebaiknya diisi air terlebih dahulu supaya perembesan ke arah luar ter- 
kurangi, ring tengah harus selalu terisi air saat pengamatan.

d. Setelah diisikan ke dalam ring tengah dengan cepat plastik ditarik dan ditambah air sampai ketinggian tertentu lalu dibaca skala penurunan air setiap 15 menit sampai penurunan air dalam silinder konstan.

e. Hal tersebut dilakukan juga terhadap titik-titik pengukuran infiltrasi lainnya.

\subsection{Daerah Resapan Air}

Daerah resapan air adalah daerah yang menjadi lokasi masuknya air dari permukaan tanah ke dalam zona jenuh air sehingga membentuk suatu aliran air tanah yang mengalir ke daerah yang lebih rendah. Daerah ini memiliki pada umumnya kandungan komposisi mineral dan komposisi garam yang lebih rendah dari daerah luahannya dalam satu aliran air tanah yang sama dan mengalami penurunan tekanan air yang berlawanan dengan kenaikantekanan air di daerah luahannya dalam satu aliran air tanah yang sama. Daerah resapan air juga terdapat perbedaan distribusi tumbuhtumbuhan. Pemahaman makna daerah resapan air di alam setidaknya ada lima unsur utama sebagai ciri yang harus dipenuhi yaitu kondisi tanahnya poros, kemampuan dalam meresap air yang cukup tinggi, memiliki perbedaan tinggi air tanah yang mencolok, berada pada wilayah dengan curah hujan cukup tinggi $>2500 \mathrm{~mm} /$ tahun, dan memiliki vegetasi dengan sistem perakaran yang cukup dalam serta memiliki pelapisan tajuk.
Dalam penilaian kawasan resapan air ini secara umum dijelaskan dalam diagram alir seperti ditunjukkan pada Gambar 2.

\section{Hasil dan Pembahasan}

Besarnya laju Infiltrasi dapat diperoleh dari pengukuran dilapangan dengan menggunakan alat infiltrometer. Adapun data hasil pengukuran laju infiltrasi selama interval $\mathrm{t}=5$ menit dari 3 titik penelitian di Tosari, Lumbang, dan Winongan.

\section{a. Desa Tosari}

Desa Tosari terletak di kaki Gunung Bromo dengan kondisi lahan relatif curam dan jenis tanah berbatu.

Besarnya laju infiltrasi di Tosari sesuai dengan hasil penyelidikan langsung di lapangan menunjukkan nilai 4,80 $\mathrm{cm} / \mathrm{jam}$ atau $48 \mathrm{~mm} / \mathrm{jam}$ (Tabel 2 dan Gambar 3).

Tabel 2. Hasil Pengukuran Laju Infiltrasi Desa Tosari

\begin{tabular}{cccc}
\hline No. & $\begin{array}{c}\text { T } \\
(\text { menit })\end{array}$ & $\begin{array}{c}\text { Penurunan } \\
(\mathrm{cm})\end{array}$ & $\begin{array}{c}\text { Laju Infiltrasi } \\
(\mathrm{cm} / \mathrm{jam})\end{array}$ \\
\hline 1 & 5 & 3,50 & 42,00 \\
\hline 2 & 10 & 3,00 & 36,00 \\
\hline 3 & 15 & 3,00 & 36,00 \\
\hline 4 & 20 & 2,70 & 32,40 \\
\hline 5 & 25 & 2,50 & 30,00 \\
\hline 6 & 30 & 2,10 & 25,20 \\
\hline 7 & 35 & 1,50 & 18,00 \\
\hline 8 & 40 & 1,40 & 16,80 \\
\hline 9 & 45 & 1,30 & 15,60 \\
\hline 10 & 50 & 1,00 & 12,00 \\
\hline 11 & 55 & 0,80 & 9,60 \\
\hline 12 & 60 & 0,40 & 4,80 \\
\hline 13 & 65 & 0,40 & 4,80 \\
\hline 14 & 70 & 0,40 & 4,80 \\
\hline
\end{tabular}

b. Desa Lumbang

Pengujian selanjutnya adalah di Desa Lumbang yang terletak di hulu Mata Air Umbulan dan sisi utara Gunung Bromo. 


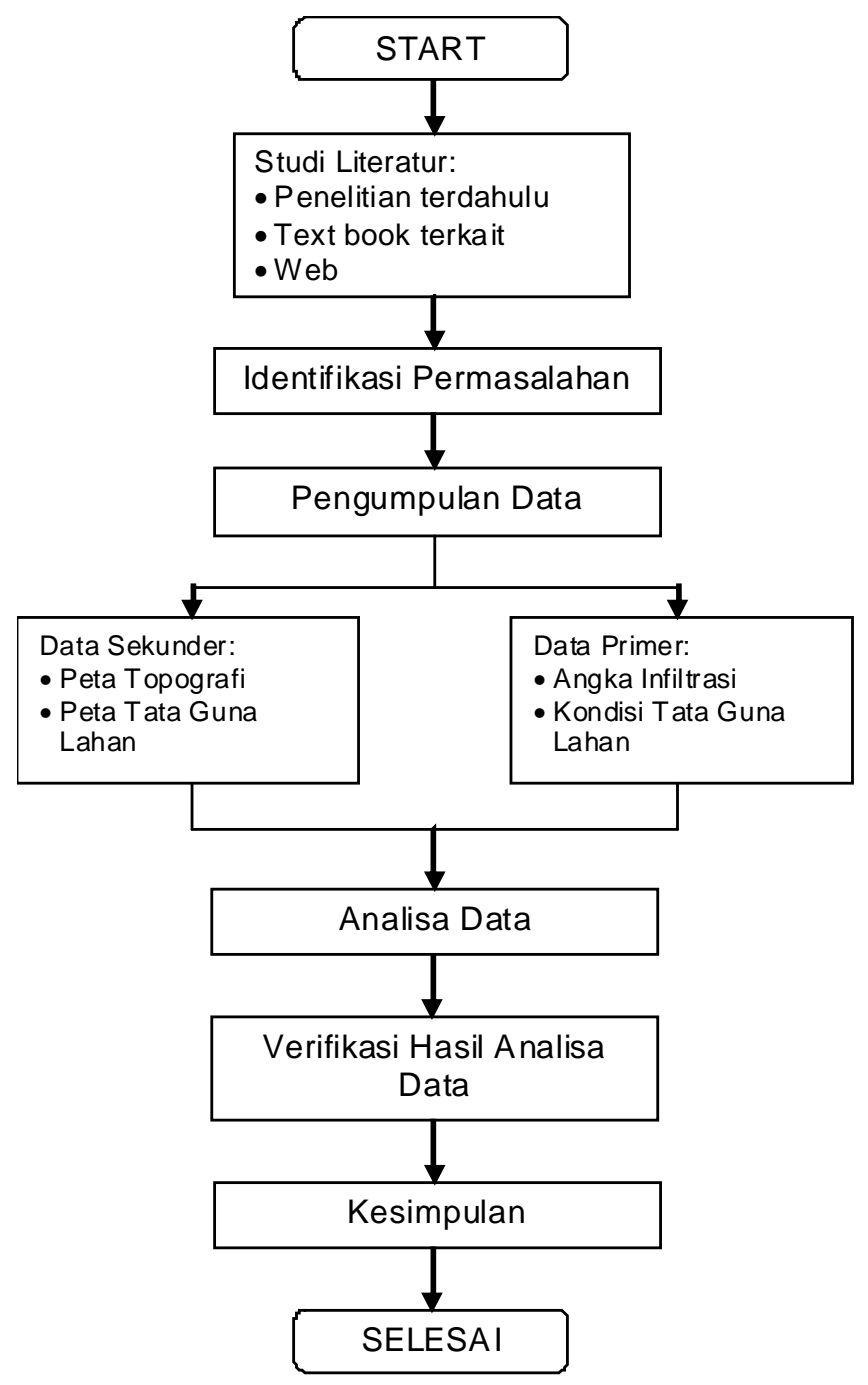

Gambar 2. Diagram alir penelitian

Tabel 3. Hasil Pengukuran Laju Infiltrasi Desa Lumbang

\begin{tabular}{cccc}
\hline No. & $\begin{array}{c}\text { T } \\
\text { (menit) }\end{array}$ & $\begin{array}{c}\text { Penurunan } \\
(\mathrm{cm})\end{array}$ & $\begin{array}{c}\text { Laju Infiltrasi } \\
(\mathrm{cm} / \mathrm{jam})\end{array}$ \\
\hline 1 & 5 & 4,50 & 54,00 \\
\hline 2 & 10 & 4,50 & 54,00 \\
\hline 3 & 15 & 4,00 & 48,00 \\
\hline 4 & 20 & 3,50 & 42,00 \\
\hline 5 & 25 & 3,50 & 42,00 \\
\hline 6 & 30 & 3,00 & 36,00 \\
\hline 7 & 35 & 1,50 & 18,00 \\
\hline 8 & 40 & 1,30 & 15,60 \\
\hline 9 & 45 & 1,00 & 12,00 \\
\hline 10 & 50 & 1,00 & 12,00 \\
\hline 11 & 55 & 0,90 & 10,80 \\
\hline 12 & 60 & 0,70 & 8,40 \\
\hline 13 & 65 & 0,70 & 8,40 \\
\hline 14 & 70 & 0,70 & 8,40 \\
\hline
\end{tabular}

Nilai laju infiltrasi yang diperoleh dari pengujian dengan ring infiltrometer di Desa Lumbang adalah sebesar 8,40 $\mathrm{cm} / \mathrm{jam}$ atau $84 \mathrm{~mm} / \mathrm{jam}$ (Tabel 3 dan Gambar 4). nilai tersebut lebih besar daripada nilai di Desa Tosari disebabkan karena kondisi geologi titik pengambilan sampel di Desa Lumbang merupakan daerah agak berpasir, tutupan lahan berupa semak dan kemiringan lahan yang relatif curam sehingga laju infiltrasi yang terjadi relatif besar. 


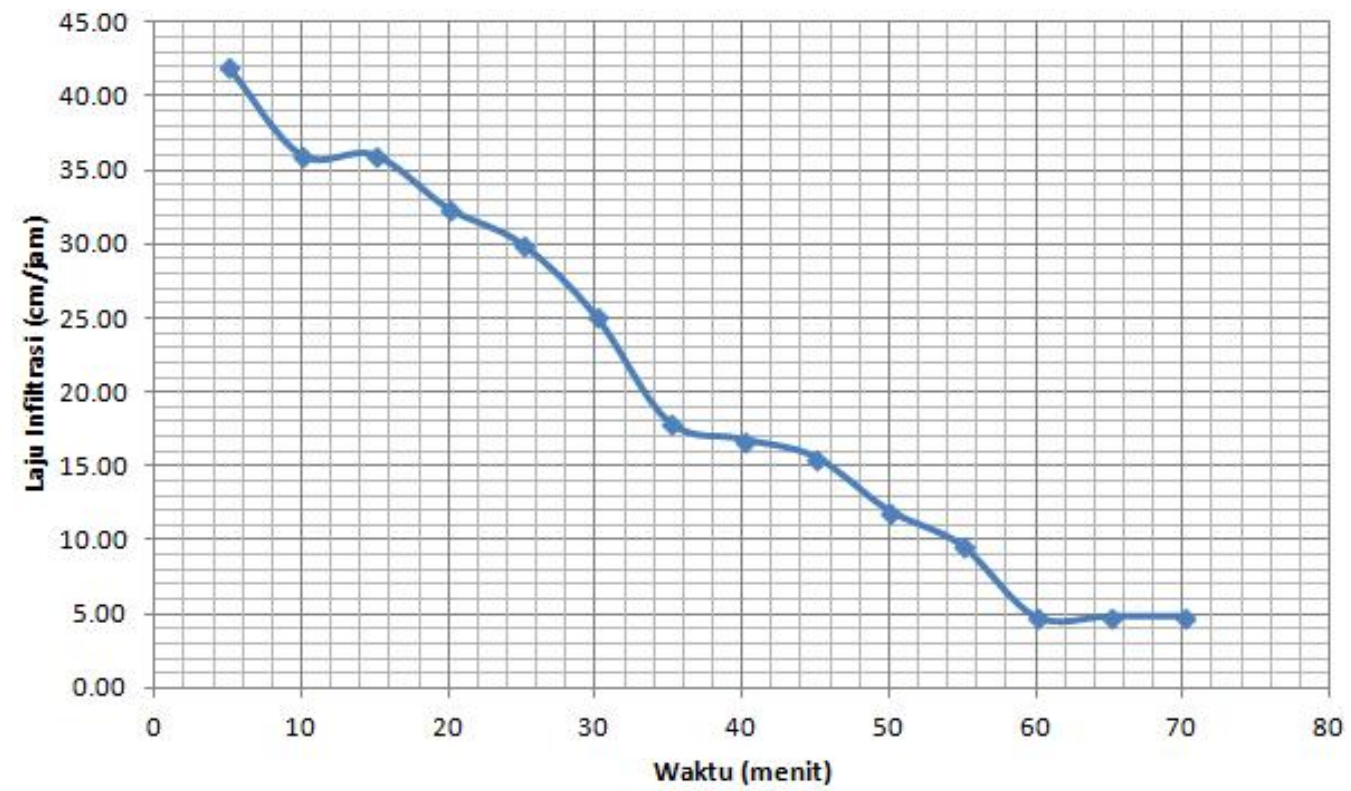

Gambar 3. Grafik Laju Infiltrasi di Tosari

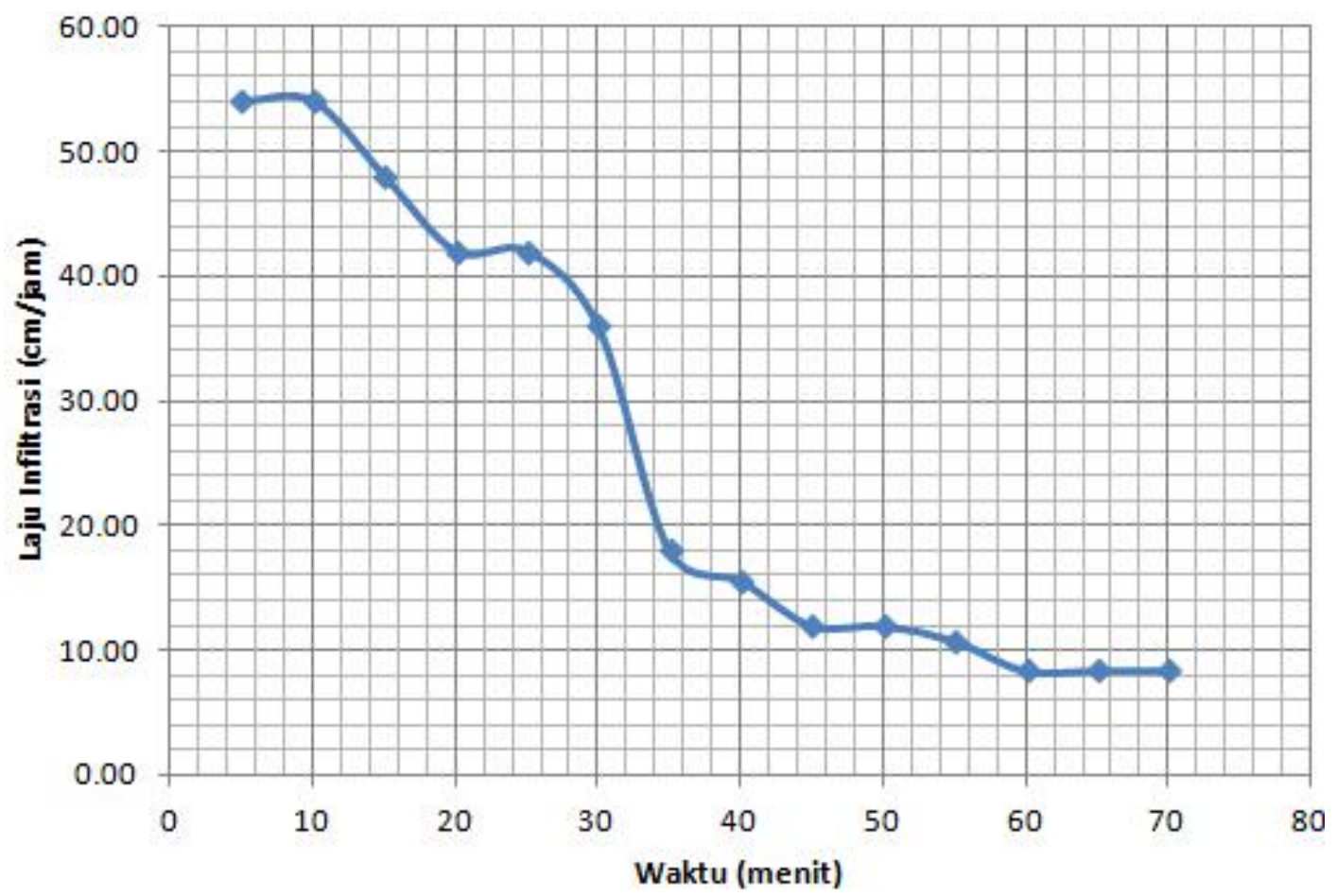

Gambar 4. Grafik laju infiltrasi di Lumbang

c. Desa Winongan

Desa Winongan merupakan lokasi terdekat dengan Mata Air Umbulan dengan kondisi lahan berupa aluvial dan tutupan lahan vegetasi budidaya. Titik pengambilan nilai laju infiltrasi ketiga ini dimaksudkan untuk mengetahui nilai laju infiltrasi yang berada di dekat mata air sebagai perbandingan dengan titik pengamatan lain yang mengambil lokasi di hulu Mata Air Umbulan (Tabel 4 dan Gambar 5). 
Tabel 4. Hasil Pengukuran Laju Infiltrasi Desa Winongan

\begin{tabular}{cccc}
\hline No. & $\begin{array}{c}\text { T } \\
(\text { menit })\end{array}$ & $\begin{array}{c}\text { Penurunan } \\
(\mathrm{cm})\end{array}$ & $\begin{array}{c}\text { Laju Infiltrasi } \\
(\mathrm{cm} / \mathrm{jam})\end{array}$ \\
\hline 1 & 5 & 2,50 & 30,00 \\
\hline 2 & 10 & 2,50 & 30,00 \\
\hline 3 & 15 & 2,00 & 24,00 \\
\hline 4 & 20 & 2,00 & 24,00 \\
\hline 5 & 25 & 1,50 & 18,00 \\
\hline 6 & 30 & 1,50 & 18,00 \\
\hline 7 & 35 & 1,50 & 18,00 \\
\hline 8 & 40 & 1,25 & 15,00 \\
\hline 9 & 45 & 1,00 & 12,00 \\
\hline 10 & 50 & 0,50 & 6,00 \\
\hline 11 & 55 & 0,30 & 3,60 \\
\hline 12 & 60 & 0,50 & 6,00 \\
\hline 13 & 65 & 0,50 & 6,00 \\
\hline 14 & 70 & 0,50 & 6,00 \\
\hline
\end{tabular}

Nilai laju infiltrasi yang diperoleh dari pengujian dengan ring infiltrometer di Desa Winongan adalah sebesar 6 $\mathrm{cm} / \mathrm{jam}$ atau $60 \mathrm{~mm} / \mathrm{jam}$. Nilai tersebut lebih kecil daripada nilai di Desa Lumbang disebabkan karena kondisi geologi titik pengambilan sampel di Desa Winongan merupakan daerah tanah aluvial, tutupan lahan berupa tanaman budidaya dan kemiringan lahan relatif datar sehingga laju infiltrasi yang terjadi tidak sebesar daerah yang curam.

\section{Simpulan}

Berdasarkan rangkaian penelitian yang telah dilakukan, didapatka beberapa hasil yang dapat memberikan gambaran mengenai kondisi resapan Mata Air Umbulan. Adapun hal yang dapat disimpulkan dari hasil analisa adalah sebagai berikut:

a. Lokasi penelitian untuk menentukan resapan Mata Air Umbulan adalah Desa Tosari yang terletak di kaki Gunung Bromo dan merupakan hulu Mata Air Umbulan, Desa Lumbang (tengah-tengah antara Gunung Bromo dengan Mata Air Umbulan), dan Desa Winongan yang merupakan lokasi terdekat dengan Mata Air Umbulan.

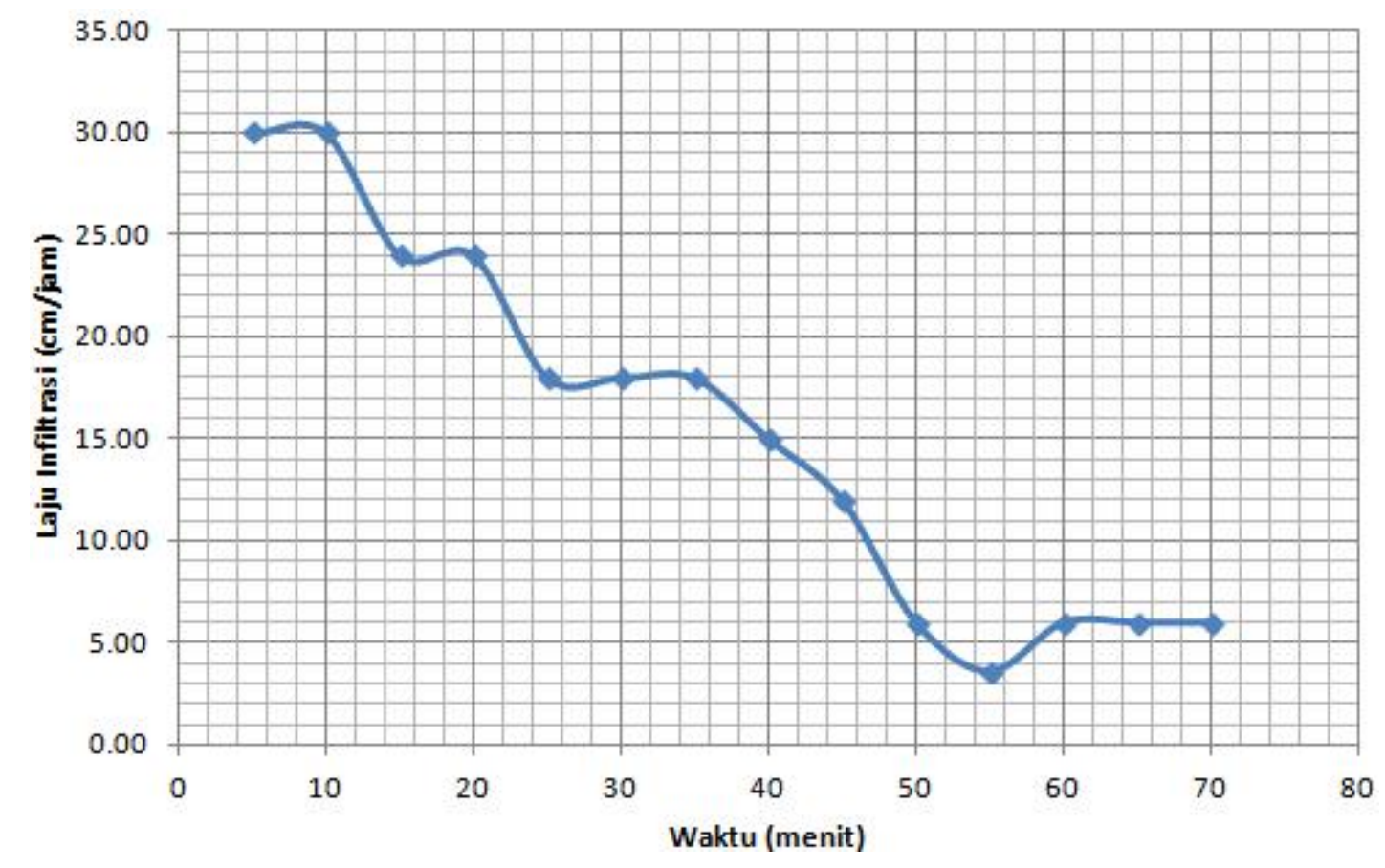

Gambar 5. Grafik laju infiltrasi di Winongan 
b. Hasil pengujian di lapangan menunjukkan nilai laju infiltrasi di Tosari sebesar $48 \mathrm{~mm} / \mathrm{jam}$, Desa Lumbang $84 \mathrm{~mm} / \mathrm{jam}$, dan Desa Winongan 60 $\mathrm{mm} / \mathrm{jam}$.

c. Nilai infiltrasi Desa Tosari menunjukkan gambaran bahwa daerah tersebut memiliki kemampuan resapan yang cukup baik sehingga dapat menjadi penyangga Sub CAT Umbulan. Namun kondisi kelerengan yang cukup curam menyebabkan daerah tersebut relatif tidak dapat menyimpan air tanah dalam jumlah besar karena aliran air tanah akan terakumulasi ke cekungan di daerah bawah. Nilai infiltrasi Desa Lumbung dan Winongan menunjukkan kemampuan daerah tersebut sangat baik. Daerah tersebut merupakan daerah dataran yang tersusun oleh material dari endapan aluvial sungai dengan potensi air tanah yang cukup besar.

Berdasarkan hasil pengujian nilai infiltrasi yang telah dilakukan di lapangan dapat disimpulkan bahwa nilai infiltrasi ditentukan oleh stuktur geologi dan kemiringan lahan.

\section{Daftar Pustaka}

Asdak, Chay., (2010). Hidrologi dan Pengelolaan Daerah Aliran Sungai, Jakarta: Gadjah Mada University Press

Seyhan. (1990). Dasar-Dasar Hidrologi, Yogyakarta: Gadjah Mada University Press

Sosrodarsono, Suyono dan Takeda, Kensaku. (1993). Hidrologi untuk
Pengairan, Jakarta: Pradnya Paramitha

Tricker, Alan S., The Infiltration Cylinder: Some Comments on Its Use. Journal Hydrology., 36: 383 - 391 
Halaman ini sengaja dikosongkan 